\title{
MARKETIZATION ALLOCATION, LAND PRICE, AND LOCAL GOVERNMENT LAND SPECULATION, CHINA
}

\author{
Juanfeng ZHANG (iD) ${ }^{1,}$, Lele $\mathrm{LI}^{1}$, Ting YU ${ }^{1}$, Danxia ZHANG ${ }^{1}$, \\ Guochao ZHAO ${ }^{1}$, Haizhen WEN (D) ${ }^{2}$ \\ ${ }^{1}$ The College of Management, Zhejiang University of Technology, 310023, Hangzhou, China \\ ${ }^{2}$ Center for Real Estate Studying, Department of Civil Engineering, Zhejiang University, 310058, Hangzhou, China
}

Received 13 June 2019; accepted 18 January 2020

\begin{abstract}
Land value appreciation in the urbanization process has triggered market speculation. The Land Bank System strengthens local governments' ability to control land supply and distribution rights. Local governments are considered close stakeholders. Under the pressure of guaranteeing economic growth and promotion, local governments have increased their dependence on land finances. It is important for investors to understand the local governments' behaviors, and draw up business strategies. This study aims to examine the influencing factors and formation mechanism of local government land hoarding. The research hypothesis was tested by collating provincial-level panel data of China from 2004 to 2015 and using dynamic panel data estimated by the Generalized Method of Moments (GMM). A significant positive correlation was found between residential land price and land hoarding area by local governments. Land speculation in the eastern region is also more pronounced than that in central and western regions. In addition, empirical studies have found a correlation between the degree of government intervention and local government land hoarding behavior. The higher the degree of government intervention, the less land sold through bid invitation, auction, and listing, which are linked to the corresponding hoarding land area.
\end{abstract}

Keywords: local government, land hoarding, land price, GMM, China.

\section{Introduction}

Investment and speculation are different types of business behavior. Speculation is a short-run phenomenon, referring to a business behavior that pursues short-term economic benefits. Speculators tend to buy assets with the expectation that a profit can be earned from subsequent price volatility. Investment involves putting money into an asset which is not necessarily marketable in the short run. So, investment involves long-term expectations about certain assets. The distinction between investment and speculation is the role of expectations. Speculation involves a high level of risk and uncertain expectation of returns. In China's land system, local governments are monopolists who actually pursue land revenue maximization. So, the local governments are taken as land sellers capturing short-term profit on land market. It is important for investors, understanding the behaviors of Chinas local governments on the land market, to draw up their business strategies and inform their own competitive positions within the real estate industry (Liu et al., 2018a; Remeikienè et al., 2019).
Land speculation is an economic phenomenon in urbanization and a strategic advance used by speculators hoarding lands for future high returns. Along with the prosperity, recession, and depression in the economic cycle, widespread speculations have been reported, such as in Chicago in 1830-1933, Philadelphia in 1945-1962, Seattle in 1956-1966, England in 1960-1970, Jordan in 19751983, and Hainan in 1990-1993 (Quaife \& Hoyt, 1934; Tewfik, 1989). Studies have shown that land speculation is an important factor in the formation of real estate price volatility and asset bubbles (Goodman \& Thibodeau, 2008; Hui et al., 2017). Moreover, land speculation is always accompanied by land hoarding, which directly affects the timing, use, and scale of market supply. Areas undergoing rapid urbanization can often perceive contradictions. On the one hand, land prices continue to rise and demand is strong. On the other hand, hoarding causes land vacant and idle. As a result, long-term development has not led to effective land use within such areas. Neutze $(1968,1970)$ argued that the key strategies in land speculation are to

${ }^{*}$ Corresponding author. E-mail: juanfengzh@hotmail.com 
hoard undeveloped, potential, and readily tradable land and wait for the opportunity to obtain high profits. Land speculation is objectively helpful in supporting urban developments and maintaining economic vibrancy, such as in Seattle and Indonesia (Rancich, 1970). Land represents all aspects of developed properties (e.g., location, amenities, and option value), making market value higher than cost (Davis, 2009). Other things being equal, a large share of land area evidently accounts for real estate price fluctuations (Nichols et al., 2013). Furthermore, when land speculation becomes extreme to generate price bubbles, the social and economic systems may be harmed. Such as the Great Depression of the United States in the 1930s originated from land speculation; the collapse of land price bubbles also brought Japan into the "lost decade" (Okumura, 1997). The 2008 financial crisis in the United States was also accompanied by a burst of real estate price bubbles, a sharp drop in land prices, and a decline in investments, which had a serious impact on the global economy (Liu et al., 2018b).

In the context of globalization, urban development has been an important driver of economic growth over the past decades. Urban growth controls can preserve open space and other amenities but may come at the expense of high land and housing prices (Mercy, 2011). China's economic integration into globalization has resulted in the gradual transformation of land resources from planned distribution to market al.ocation. Large-scale land development has been implemented nationwide, and the country has entered the booming cycle of the real estate market and fast lane of urbanization (Ho \& Lin, 2003). Since China’s Reform and Opening, urbanization has been characterized by an unprecedented amount of land development resulting from land marketization and commodification (Huang
\& Chan, 2018). In order to improve land use efficiency, the Chinese government separated land use rights from land ownership in the 1980s (Lin \& Ho, 2005). Since the reform and opening up of special economic zones in 1979, foreign-funded and private enterprises have required legal and clear and legal property rights. In 1988, the constitutional amendment adopted "allowing land use rights to be transferred in accordance with the law," through which private enterprises can obtain land use rights. In 2002, the Ministry of Land and Resources promulgated the Regulations on the Transfer of State-owned Land Use Rights by Bidding, Auction, and Listing. Urban land use rights must be transferred by means of bidding, auction, or listing. The marketization level has further improved, while allocation and agreement methods have been retained.

The land use system reform clarifies that residential development requires urban state-owned land, which can only be obtained from the government through bidding, auction, and listing. Local governments monopolize urban land supply, which is handled by real estate development. During marketization and urbanization, the role of government is affected by economic interests. Local governments are the regulators of land resource use and suppliers of land markets. Institutional arrangements of referees and athletes are regarded as one, thus making the reconciliation of roles and functions difficult. The restriction of urban land supply has various effects on real estate destocking over different time periods and under the influence of the development status of different cities (Shen et al., 2018). Given the rising land prices during 2004-2015, local government land hoarding and land income were remarkable. Both are important factors affecting social and economic development, as shown in Figure 1.

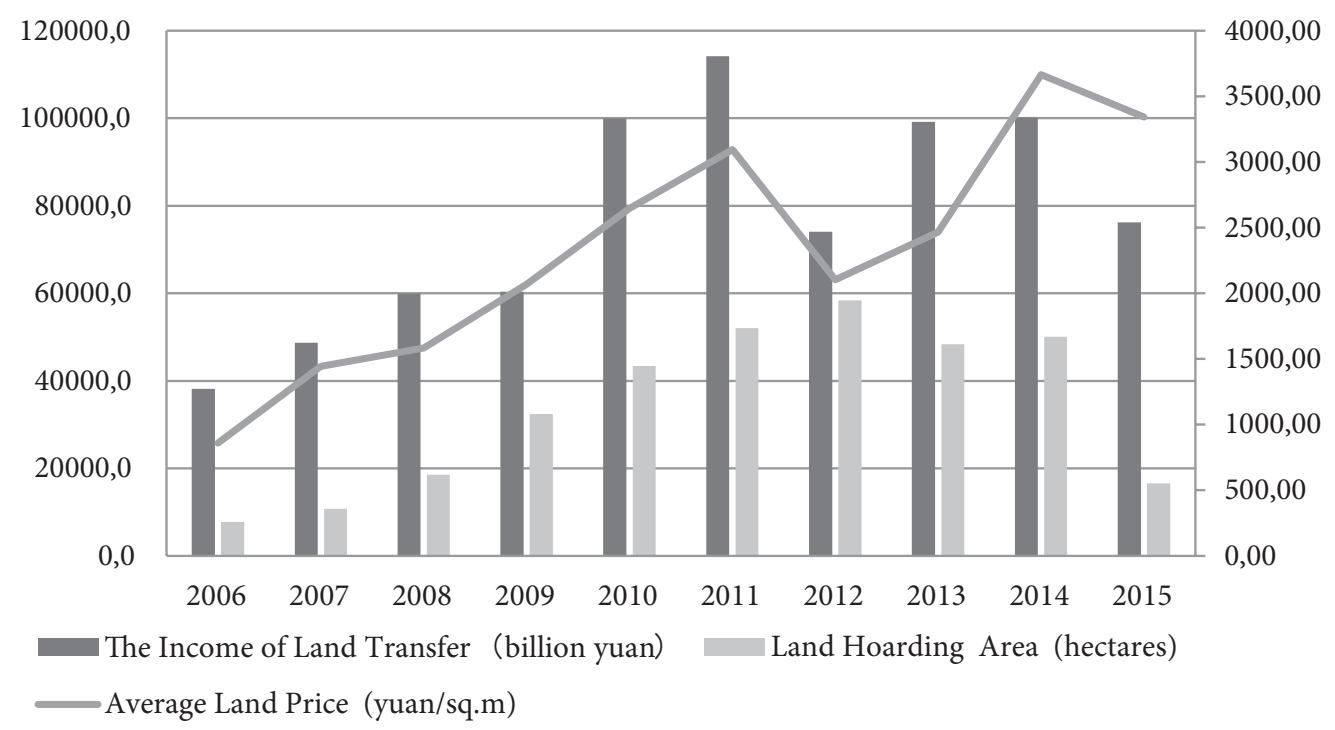

Figure 1. China’s average land price, land income, and land hoarding from 2006 to 2015

Note: Data sources: China Statistical Yearbook of Land and Resources (2007-2016), all the data is got from open resources, and the copyright is permitted legally. 
In the current Chinese land system, there are two types of land ownership, state-ownership and collectiveownership. Industrial land use rights can be transferred to different land lease terms (Ye et al., 2018). A long-term equilibrium exists between urban housing and land market in China. These policies may have adverse side effects (Koster et al., 2012). Land use regulations may also reduce property value (Grout et al., 2011). Since 2004, the new land grant institution in China has resulted in low efficiency due to the housing and land market information asymmetry imbalance (Du et al., 2010).

In relation to other private land speculations and land hoarding behaviors, this study focus on local governments, influencing factors, and formation mechanisms. On the basis of the three dimensions, the following questions have been addressed. (1) Does market price affect local government land hoarding scale in Chinese land system? (2) Does the degree of land marketization and government intervention affect land hoarding scale? (3) Does local governments' land financial dependence affect land hoarding scale? The paper is organized in the following manner. The first part presents the literature review. The second part discusses the research hypotheses and empirical model. The third part explains the research area and variable description. The fourth part is the empirical result and the final part provides the conclusion.

\section{Literature review}

\subsection{Land speculation and hoarding behavior}

Land scarcity and regulation lead to the short-term lack of elasticity in supply. As a result, land is high quality speculative goods. Land speculation occurs when investors' expecting return is higher than the land holding cost. Land price and fluctuation are the important influencing factors of land hoarding. Land speculative income mainly comes from the difference between land prices and rent fluctuation, whereas cost includes opportunity cost, land holding interest, and related taxes and fees (Bentick, 2010a). If land hoarding cost is relatively stable and land prices are expected to rise, then the market hoarding behavior becomes active. On the one hand, rapid urbanization promotes large-scale land development. When rising expectations are formed, they attract additional capital to perform land hoarding (Lavin \& Zorn, 2001). On the other hand, adequate capital and a relaxed financing environment in society are also factors in promoting land hoarding, and capital must find suitable investment opportunities (Schmid, 1968). Margin profit can further squeeze the investment opportunities of the real economy, and speculators thus tend to hoard more land. As far as speculators are concerned, they can be divided into individuals, developers and governments. With the establishment of the urban land reserve system and approach of the land development supervision system, developers' land speculation has nearly been regulated.
Uncertainty and price volatility in the land market are necessary conditions for land speculation. New economies, booming real estate markets, and rising housing prices increase the demand for residential property, which helps investors maximize land gains. Fluctuations in real estate prices are often considered good speculative opportunities. The best option for landholders is to keep land vacant so that it can be traded for profit. When the land enters the development and construction stage, land transaction becomes complicated and difficult. Thus, obtaining vacant property rights and easy-to-trade land is an important condition (Bentick, 2010b). Holding vacant land inevitably results in a certain cost for holders. Hoarding cost is an important factor affecting holding scale. It can also be summarized as the opportunity cost, interest, and tax cost of land (Bourassa et al., 2010). When the speculator is the government, hoarding cost only includes opportunity and interest costs and the government does not need to pay corresponding taxes. Property tax is considered a regulator between land income and holding cost. The imperfection and lack of property tax system is considered an important reason for land speculation. Farmland protection policy is also a factor in promoting land price increases, such as in China and Japan (Lichtenberg \& Ding, 2008). In response to housing speculations, the Netherlands proposed a solution from the municipal land supply system and new housing policy (Golland \& Boelhouwer, 2002). Some studies have discussed the effect of property taxes on land and housing speculation. The literatures assess the differential effects of increasing land value and taxation by comparing urban and undeveloped land, buildings, and vacant land and rent and sale prices. The results of the study show that tax is ultimately borne by consumers. For the booming land market, observing the tax design of land prices is necessary to further stimulate land speculation.

Hui (2004) focused on the impact of demand on land, but rarely considered the impact of land supply. Furthermore, land market has a dual nature, which means that the government owns most land that can be developed but are mainly completed by real estate developers (Ooi et al., 2011). Researches on land speculation and hoarding focus on private and corporate investment behaviors. However, government land speculation is still lacking. Du and Peiser (2014) investigated the land hoarding issue involving the Chinese local governments by using provincial-level data from 1995 to 2010 to assess the relationship between land prices and land scale held by local governments. They found that the local governments' land hoarding scale is closely related to the land market condition. For every one-yuan increase in land prices, the local governments' land hoarding increases by 40.8 hectares. In countries with institutional transition, government's deep involvement in economic development is an important feature. The rational motives of the local governments' land hoarding expect the price fluctuation of the land market and decide the opportunity to sell to increase land transfer income. Before entering the land hoarding pool, the local 
governments must pay the development cost. Agricultural land use for non-agricultural construction must be requisitioned firstly. Farmers involved are compensated according to the corresponding administrative standard rate, and the government receives the full land appreciation value (Du \& Peiser, 2014). Local governments can obtain favorable commercial loans to support their land hoarding. If land prices remain stable and keep rising, then the revenue of local governments' land hoarding remains stable (Su et al., 2012). Conversely, if the real estate market (which is correlated with the land market) fluctuates, then the expected change can greatly influence land revenue and hoarding scale.

\subsection{Land marketization and land finance}

Land supply is the basic material constraint of urban sprawl. Therefore, land market plays a critical role in urban development (Zhang et al., 2017). State-owned construction land is the only legal land source for urban development in China, and its supply influences urban expansion, house prices, and economic development (Jiang et al., 2016). The basic logic of China's land system reform is to promote land as a stimulating lever for economic development. On the one hand, local governments can make lucrative land revenues as urban infrastructure financing. They can also use low price land as an important bargaining chip for investment promotion. Under the land market al.ocation mode, local governments sell land through public bidding, auction, and listing, which are considered market-oriented methods. Therefore, the proportion of bidding and auction in land transfer is regarded as the degree of land marketization. A competitive land market can generate high land prices and land revenue. In 2002, the Ministry of Land and Resources adopted this approach and required land for development (including commercial, tourism, entertainment, residential use) to be sold through tendering, bidding, and listing. As manufacturing and industrial production shift to areas with low land costs, local governments face fierce competition to attract and hold this type of investment. "Bottom line competition" is a common strategy for local governments to attract industrial investment with low-price industrial land.

It is believed that local governments' land hoarding is also related to central and local fiscal system arrangements. In 1994, the central and local governments implemented a tax-sharing system. Land grant premiums and land tax revenues have become two major sources of fiscal revenues for local governments in China (Wu et al., 2015a). Budget deficit is a common fiscal pressure that Chinese cities deal with (Wu et al., 2015b). Local governments must look for new sources of funds outside the taxation to complete the huge economic development plan. An important indicator of land market reform is that the land reserve system, bidding and auctioning methods are established in the form of laws and regulations. Land has become an important source of income for local govern- ments and is a high-quality financing collateral (Wang et al., 2012). The local governments monopolize the supply of land through bidding, auction, and land transfer complicates the urban land price formation mechanism of China (Wen et al., 2018). The huge land revenue is distributed between the central and local governments, and more than $90 \%$ of the proceeds are used by local governments. The tax-sharing reform is an adjustment to the distribution of fiscal revenues between the central and local governments. The policies also strengthen the central government's intervention in the degree of freedom of local fiscal control. In a certain sense, tax-sharing reform strengthens the marginal tendency of local governments to directly obtain the current fiscal revenue through land transfer fees. Therefore, local governments are bound to depend on land finance. As local governments experience financial pressures, the sharp rise in land sales supports the assumptions of local officials using land finance to stimulate economic development (Dong, 2016). Although certain risks are involved in these behaviors, the benefits of increased local fiscal revenues to local finances are significant. As a result, local governments tend to hoard, which is also affected by other factors. As the market environment is still not perfect, governments act as mediators in the land market. Local governments have limited land resources, and developers' optimistic expectations for future land appreciation have intensified the overheating of land market investment.

The tax-sharing system forms a single-share tax and a shared tax between the central and local governments. After implementing the tax-sharing fiscal reform, the central government's financial situation significantly improved, and the surplus increased. However, the local governments' debt continued to rise. Land income has become the main source of local governments' revenue. Only $10 \%$ of the total government investment in infrastructure comes from the local tax and fee. The remaining $90 \%$ is provided by land sales income or land mortgage loans. In this context, local governments must find appropriate sources to support the infrastructure for rapid urbanization. To make up for the serious fiscal deficit, urban construction land is an important asset of local governments, and the high land price is a prerequisite for maintaining land revenue. In 2007, the establishment of the urban land reserve system was aimed at improving the land reserve system, strengthening land regulation, regulating land market operations, promoting land conservation and intensive use, and improving the construction land support capacity. Land transfer revenue has become an important source for local governments to promote infrastructure construction and urban development. In addition, maximizing land revenue is a realistic goal for local governments. The special land systems have made local governments land speculation different from foreign speculation. Local governments' land speculation constantly changes due to the evolution of land marketization and system. The low degree of land market transaction restriction indicates that government 
intervention is less than expected, resulting in low hoarding scale. In the same way, the higher the degree of financial dependence on the land, the higher the hoardings scale by the government. Studies have shown that land revenue is important for local governments. As a result, local governments become incentives for land speculation for maximum benefits. However, this inference still lacks the support of empirical research.

\section{Research hypotheses and empirical model}

\subsection{Research hypotheses}

Land hoarding is a common phenomenon in the market economy and an important strategy for land speculation, which is affected by many factors. This study attempts to explore the land hoarding behavior of local governments and its influencing factors in the land marketization and urbanization in China. First, the theoretical model confirms that the impact of land price have always been considered a key variable. Thus, this study incorporates it in the model to examine the relationship between market price level and hoarding scale. Second, by paying attention to the impact of land marketization progress, the literature shows that the Land Bank System and land marketization are related to land hoarding. In the theoretical model, the degree of land marketization and intervention is included. Third, land finance reflects local governments' dependence on land revenue. The model incorporates local governments' financial dependence into the model to study its impact. Certain institutional and economic development factors also have explanatory power (Liu et al., 2018c). Thus, the following assumptions are presented.

Hypothesis 1: Local governments' land hoarding scale is positively affected by land prices.

High land prices indicate that land of the same area can receive more revenue, and local governments tend to hoard more land until the land market is booming and prices are high.

Hypothesis 2: Local governments' land hoarding scale has a negative correlation with the degree of government intervention.

The higher the degree of government intervention, the higher the proportion of agreement transfer and the less the local governments' hoardings scale.

Hypothesis 3: Local governments' land hoarding scale is positively affected by land marketization and government land financial dependence.

The degree of land marketization reflects the use of bidding or agreement price to sell land in land transfer. When the ratio of agreement is low, the degree of marketization is high. When local governments obtain a high amount from the land market, they tend to hoard more. Dependence on land revenue will also affect the government's behavior. When the land revenue proportion of local finance is high, local governments tend to hoard more land.

\subsection{Empirical model}

Land prices and land hoarding scale are key factors. However, a strong endogeneity problem is found. The ordinary least squares (OLS) method leads to estimation coefficient bias. First, a mutual influence may exist between land hoarding scale and land price level. Hoarding scale affects land price level, whereas land price level, in turn, affects hoarding scale. Second, the actual land transaction price leads to measurement errors, which are not well reflected. Third, the model uses the average residential land price level, and the measurement method is affected by the heterogeneity of different regions, uses, and locations, and certain biases also exist. To solve endogeneity problems, instrumental variables must be available. Under the current land system, the scale of urban exploitable land is approved by the central government through the quota indicator system of land use planning. The cultivated land is strictly protected and cannot be converted or developed. The amount of cultivated land is regarded as the exploitable land endowment indicator. We consider that the land price level is affected, and the amount of cultivated land does not affect the land scale. Wen and Goodman (2013) showed that per capita arable land area is negatively correlated with land prices and the amount of cultivated land in each area can be used as a instrumental variable. Second, lag economic variable can be used as a instrumental variable to solve the unpredictable price problem (Murray, 2006). This study takes the two-stage lag of land price level as another instrumental variable. To solve the measurement error, the hysteresis level of endogenous variables is usually used as a instrumental variable. Therefore, three instrumental variables are constructed in the model, namely, the ratio of cultivated land, first phase of land prices lag, and second phase of lag.

To verify the three hypotheses, an empirical model is presented in Equation 1.

$L n L D_{i t}=a_{o}+a_{i} \operatorname{LnLP} P_{i t}+a_{j} \operatorname{Ln} L M_{i t}+a_{l} L n L F_{i t}+a_{m} \operatorname{Ln} Y_{i t}+\varepsilon_{i t}$.

where: $L D_{i t}$ is a dependent variable that indicates the size of the residential land hoarded in the $t$-th period of area $i$.

Under the existing land management system, the residential land use plan (quota) is approved at the beginning of each year, indicating the residential land area that the government can use for transfer in the year. Local governments must sell land within this range and cannot break through the indicator. The local governments decide the actual transfer area according to the actual situation and can retain part of the land. This part forms the residential land that the government can hold and sell at any time. This research uses the difference between the approved residential land area and actual transfer scale in the current year as the land hoarding area.

The quotas (zhibiao) are allocated to provincial governments by central government (State Council) at the beginning of each year. So, the lawful quotas are the potential and developable land in certain province. Local 
governments cannot break through quotas, even if the land price is high profit. But the local governments have the right to hoard land, if they think it is not proper timing of selling land. So, the difference between approved quotas and actual selling can reflect the local governments' preference. Just as Du and Periser's (2014) opinions, this measurement of land speculation is approximate and not perfect. First, the approved quotas of land include rural and urban area, so the land hoarding area is overestimated for urban residential land. Besides, local governments' preference, the quantity of land sales can be affected by other factors. For example, it is long time for land acquisition and infrastructure construction. Before the necessary infrastructure projects are finished, the land cannot be put on the market.

$L P_{i t}$ is an independent variable indicating the price level of residential land in the $t$-th period of area $i$. This study employs the price level of land sales in the region to measure its impact on land hoarding. Considering that the nature of the land to be sold greatly differs from the land price level, distinguishing the nature of the land to be transferred is necessary. Residential land is a land property with high income return, and residential land price drastically fluctuates. Therefore, this research measures the land price level of the area on the basis of the price level of residential land. Furthermore, the relationship between the residential land hoarding scale and land price level is examined.

$L M_{i t}$ is an independent variable, indicating the degree of land marketization and government intervention in the $t$-th period of region $i$. The model introduces two variables to verify its impact. First, considering that agreement transfer is more affected by government factors than other modes of transfer, the extent of local governments' direct intervention to the land transfer is measured by the transfer area of the total land area as an indicator. Second, the area allocated by the government to the transfer scale reflects the relative degree of liberalization of the regional land market. A high indicator value indicates a low degree of land marketization in the region.

$L F_{i t}$ is an independent variable that indicates the land financial dependency of region $i$ in the $t$-th period. By measuring the proportion of local fiscal revenues occupied by land transfer revenues in this region, the higher the ratio, the higher the local governments' dependence on land revenue. The impact of land hoarding area is examined by the local government's financial dependence.

$Y_{i t}$ is the independent variable, and $t$ is the area of social and economic factors affecting the size of land hoarding, controlling its impact on land hoarding scale. $\alpha$ refers to the regression coefficient, and $\varepsilon_{i t}$ is the error term.

\section{Research area and variable description}

\subsection{Research area}

The State Council issued quotas for housing construction land to provincial governments, and then provincial governments decomposed the quotas to municipal gov- ernments. At present, the prefecture-level cities' data is not available. This study takes 31 provincial-level regions as research objects and collects the data of 31 provinces' land and real estate markets from 2004 to 2015 for analysis. The gross domestic product (GDP), per capita gross domestic product (PCGDP), local fiscal revenue, urban fixed asset investment, added value of the secondary and tertiary industries, and added value of urban employment in 31 provincial-level regions are derived from the China Statistical Yearbook (2005-2016). Provincial land allocation, agreement, bidding, auction, listing, transfer area, approval of residential land area, and transaction price are derived from the China Land and Resources Statistical Yearbook (2005-2016). The average land price and per capita GDP unit are yuan, the land area unit is hectare, and the local fiscal revenue and transaction price unit is 10,000 yuan.

\subsection{Variable description}

The dependent variable is the area of residential land hoarding, which is equal to the difference between the amount of potential and actual residential land development. The annual approval of the residential land area by the State Council is regarded as the scale of the government's potential land development. The transfer and allocation of residential land area is regarded as the amount of the actual government residential land development. The local governments' fiscal behaviors and economic indicators can affect land scale and price (Zhang et al., 2016). In addition to residential land premium variable, we rely on government land finance, government intervention in the land market. These factors are analyzed to measure land market environment. The four variables in the model that have an impact on the size of land hoarding are considered exogenous variables and include three instrumental variables. The definition method and expected symbol of each variable are shown in Table 1.

Endogenous variables: land hoarding scale and land price level.

1. Land hoarding scale. The scale of residential land hoarded by the local governments is in hectares. The Stateowned land for the construction of residential land supply situation in Statistical Yearbook of Land and Resources is used as an index of residential land approved by the local governments, and the land that developers purchase is regarded as the actual development of residential land. The two are subtracted to get the scale of local governments land hoarding that year. After the establishment of the land reserve system, the land transfer rights of local governments are relatively independent. Land accumulation scale can reflect the attitude of local governments in promoting land and determining whether land speculation exists.

2. Land price level. Local governments sell residential land through bid invitation, auction, and listing. Transaction price is divided by the purchase of the land area to obtain the floor price in the provinces of the average price level of the year. The unit is yuan per square. The case of residential land can be reflected by the land and real-estate developments of enterprises to purchase. 
Table 1. Variable measurement and expected impact

\begin{tabular}{|c|c|c|c|}
\hline Variable & Meaning & Unit & $\begin{array}{l}\text { Expected } \\
\text { symbol }\end{array}$ \\
\hline Land hoarding & $\begin{array}{l}\text { Area of hoarding area of land that can be sold by provincial-level } \\
\text { regional governments }\end{array}$ & Hectare & \\
\hline \multicolumn{4}{|l|}{ Endogenous variable } \\
\hline Land price level & Market price and market price level of unit land & Yuan/square & + \\
\hline \multicolumn{4}{|l|}{ Exogenous variables } \\
\hline $\begin{array}{l}\text { Government } \\
\text { intervention }\end{array}$ & $\begin{array}{l}\text { The administrative allocation/transfer of land area reflects the direct } \\
\text { intervention of local governments in land transfer. }\end{array}$ & $\%$ & - \\
\hline Land marketization & $\begin{array}{l}\text { The amount of land sold by the agreement/transfer of land area } \\
\text { reflects the degree of marketization of land allocation in the economy. }\end{array}$ & $\%$ & - \\
\hline Land finance & $\begin{array}{l}\text { The annual land revenue/local government's annual total fiscal revenue } \\
\text { reflects the local government's dependence on land revenue. }\end{array}$ & $\%$ & + \\
\hline $\begin{array}{l}\text { Second and third } \\
\text { industry added value }\end{array}$ & $\begin{array}{l}\text { The annual added value of the second and third industries is used to } \\
\text { determine the speed of urban economic growth. }\end{array}$ & billion & + \\
\hline Per capita GDP & Per capita GDP & yuan & + \\
\hline Fixed asset investment & Urban fixed asset investment & billion & + \\
\hline Employment growth & Urban employment increased compared with that of the previous year & 10,000 people & + \\
\hline \multicolumn{4}{|l|}{ Instrumental variables } \\
\hline Lag1 Land price & Lagging the land price of the first phase & $\begin{array}{c}\text { Yuan per } \\
\text { square meter }\end{array}$ & + \\
\hline Lag2 Land price & Lagging the land price of the second phase & $\begin{array}{c}\text { Yuan per } \\
\text { square meter }\end{array}$ & + \\
\hline $\begin{array}{l}\text { Agricultural land area } \\
\text { ratio }\end{array}$ & $\begin{array}{l}\text { Proportion of cultivated land area in the provinces under the } \\
\text { jurisdiction of the total area of urban and rural construction land }\end{array}$ & $\%$ & - \\
\hline
\end{tabular}

Note: Data sources: China Statistical Yearbook of Land and Resources (2007-2016) and China Statistical Yearbook (2007-2016). All the data is obtained from open resources, and the copyright is permitted legally.

Exogenous variables: land marketization, land financial dependence, and social and economic variables.

3. Land marketization. Agreement transfer refers to the behavior of the land administration department on behalf of municipal governments and land users. It determines the land prices on the basis of the announced land market value and transfers land use rights to land users. The degree of land marketization of local governments is measured by the ratio of the agreed area of the state-owned construction land to the total land area. The higher the ratio is, the lower the degree of land marketization is. Land market environment can have an impact on local governments' land hoarding behavior. If the land market environment is relatively loose, then the local governments' land transfer behavior can be affected by variables, such as land price.

4. Government intervention. In the Chinese land system, land supply mode is a powerful tool for land market intervention. Land benefits greatly contribute to the financing of local income and infrastructure (Tian \& Ma, 2008). According to the China National Land Resources Statistical Yearbook, the supply of state-owned construction land by local governments is mainly acquired through allocation, transfer, lease, and other land supply methods. Allocated land is the state-owned land use right obtained without compensation after the government approves the law. This indicator can reflect the government's intervention in the land market to a certain extent. Availability of state-owned construction land allocated in the year to sell the distribution area is divided by the total area of the year to determine the extent of government intervention, in units of $\%$. Studies have found that government regulation restrictions affect house and land prices (Ihlanfeldt, 2006). The higher the proportion of land allocated to the total transfer scale, the higher the government land market intervention and the smaller the land scale that can be auctioned.

5. Land finance. According to the Statistical Yearbook of Land and Resources, land can be sold for land revenue. This research investigates the dependence of local governments on land finance in the ratio of land fiscal revenue to the local fiscal revenue in the current year, in units of $\%$. The higher the indicator, the higher the dependence of local governments on land finances. Descriptive statistics reveal that land revenue is a major source of local governments' revenue. Thus, a large extent of financial dependence may affect local governments' land acts, incorporating factors to consider.

6. Added value of secondary and tertiary industries. According to the China Statistical Yearbook, the annual output value of the two industries of industry and service industry can be obtained. The added value of the output value of the two years is the increment of the second and 
third industries, and the unit is 100 million yuan. The added value of the second and third industries can reflect the economic vitality of the current year. Therefore, the regional economic level can indirectly reflect the enthusiasm of developers to purchase land and the motive of the government to hoard land (Deng et al., 2006).

7. Per capita GDP. The China Statistical Yearbook can obtain the annual per capita GDP level of each province. Per capita GDP is an effective tool for grasping the state's macroeconomic performance. This variable is also often used as an indicator of economic development in development economics. The higher the per capita GDP level, the higher the level of economic development and the purchasing power of residents. Therefore, this indicator can affect the behavior of government land transfer.

8. Urban fixed asset investment. The annual amount of newly added urban fixed asset investment in each province can be obtained from the China Statistical Yearbook, with a unit of 100 million yuan. The amount of investment in fixed assets can show the level of economic development in that year. The variables include the enterprises for capital construction, renovation, overhaul, and other fixed asset investment. The values show a certain period of construction and purchase of fixed assets, and businesses in this effort have cost changes off. These indicators should be included in the model to reflect the economic level.

9. Employment growth. Employment population of each province can be annually obtained from the China Statistical Yearbook. The employment population of the current year is subtracted from that of the previous year as the increase amount, with a unit of 10,000 people. The increase in the employment population can reflect the annual economic development of each region. The higher the employment growth is, the higher the economy or the larger the population inflows. This relationship stimulates the local governments to use the land for sale.

10. Proportion of cultivated land. Apart from preserving farmland, farmland protection policy has played a role in urban growth management (Zhong et al., 2018). The area of cultivated land and that of urban and rural construction land in each province can be obtained each year. The ratio is used to measure the cultivated land, and the unit is \%. The amount of cultivated land is strictly protected, and therefore accounted arable land affects the amount of land supply but does not affect the size of land hoarding. Thus, the proportion of arable land is included in the model as an instrumental variable for consideration.

\section{Empirical result}

\subsection{Endogenous test and instrumental variable selection}

The price of residential use in Formula (1) is an explanatory variable, and the literature suggests that endogenous testing is required. The McKinnon endogenous test reveals that the $\mathrm{p}$ value is 0.0062 . Under the $1 \%$ significance level, the null hypothesis is rejected. Therefore, the model memory endogenous problem must be processed by instrumental variables. To adopt an appropriate estimation method, the error structure of the model must be tested. The results in Table 2 confirm that the Wald test results strongly reject the null hypothesis of the same variance. Inter-group heteroscedasticity is also considered.

Table 2. Wald heteroscedasticity test

\begin{tabular}{|l|c|c|}
\hline Wald test & Fixed effects model & $\begin{array}{c}\text { Feasible generalized } \\
\text { least squares }\end{array}$ \\
\hline Chi & 924.30 & 3910.16 \\
\hline P. value & 0.0000 & 0.0000 \\
\hline
\end{tabular}

The model has three instrumental variables: (1) the proportion of cultivated land area in each province to the total area of urban and rural construction land and (2) the first- and second-order lag terms of land price. Instrumental variables may have weak correlations and endogeneity problems that require instrument variables to be detected. We have verified that the instrumental variable is qualified by a weak instrumental variable test. Table 3 shows that the null hypothesis cannot be rejected, and a strong correlation exists between the instrumental and endogenous variables of residential land price.

Table 3. Weak instrumental variables test

\begin{tabular}{|l|c|}
\hline \multicolumn{1}{|c|}{$\begin{array}{c}\text { Cragg-Donald Wald F } \\
\text { statistic: } 4.393\end{array}$} & $\begin{array}{c}\text { Stock-Yogo weak ID test } \\
\text { critical value }\end{array}$ \\
\hline $10 \%$ maximal IV size & 19.93 \\
\hline $15 \%$ maximal IV size & 11.59 \\
\hline $20 \%$ maximal IV size & 8.75 \\
\hline $25 \%$ maximal IV size & 7.25 \\
\hline
\end{tabular}

Through the over-identification test, the $\mathrm{p}$ value in the result is greater than $0.01,0.05$, and 0.10 . Therefore, the original hypothesis cannot be rejected. That is, the instrumental variables satisfy the exogenous hypothesis and can be applied to the model. In summary, the instrumental variables selected in this study are valid. So, 2SLS is effective under the predetermined spherical perturbation term. But if there is heteroscedasticity or autocorrelation, the GMM estimate is more efficient.

\subsection{Results and analysis}

\subsubsection{Impact of land price on local governments' land speculation}

OLS, fixed effects, and dynamic GMM estimates are simultaneously performed on the data of 31 provinces. Instrumental variables (IVs) are also used to estimate the model coefficients. Table 4 presents the estimated results. After many adjustments and models running, the current results are acceptable. In the models $1-4$, the adjusted $\mathrm{R}^{2}$ is not high, and the samples basing on provincial panel data which would affect adjusted $\mathrm{R}^{2}$ value. Positive results 
between land price and residential land hoarding size can be observed, and coefficients in the model are significant. According to the estimation results, a one unit increase in the land price per square meter of residential land from 2004 to 2015 increased the residential land hoarding scale by 0.59 hectares, whereas the least squares and fixed effects methods do not consider the endogeneity of the variables. Thus, the results are insignificant. After dealing with the endogenous problem of residential land price, the positive impact on the scale of local governments' residential land hoarding becomes evident. The empirical results show that the increase in residential land price in the land market can affect the pace and behavior of local governments. When residential land price rises, local governments tend to hold more residential land, indicating that local governments may speculate in the land market.

Model 1 in Table 4 presents the estimation results when government intervention variables are the only factors included. The dynamic GMM estimation results reveal a significant positive correlation between local governments' hoarding area and land price. A one unit increase in the price of the land results in the rise of local governments' land hoarding area by 0.29 hectares. By contrast, Model 2 and Model 3 reveal the estimation results when the degree of marketization and government land finance dependence are the only variables added. But, when the three variables are put in model 4 , the result is insignificant. The limited sample data and addition of control variables that affect the significance of the model may be the reasons for insignificance.

\subsubsection{Impact on land speculation of government intervention}

To further observe the influence of exogenous factors, this study establishes a model to integrate government intervention, land market environment, and land financial dependence for dynamic GMM estimates. The new model is compared to OLS method and fixed effects model. Table 4 provides the results.

Although the added partial explanatory variables are significant in the regression results of the least squares and fixed effects methods, the land price of the key explanatory variables is insignificant, and neither of these methods considers land price endogeneity. By contrast, dynamic GMM estimates consider the land price endogeneity, and their conclusions are credible. Among them, government intervention has a negative impact on land hoarding (coefficient, -0.28 ), and the coefficient is significant, thus supporting Hypothesis 2. The GMM estimation results presented in Model 2 and Model 3 in Table 4 reveal that in addition to the negative effects of land market environment, financial dependence and land hoarding, the line number is insignificant and cannot be used to explain land market and land finance dependence on the relationship with government land hoarding.

Intervention in the land market is partly a reflection of the attitude of local governments. In terms of the degree of freedom of land allocation, administrative allocation is an effective means for local governments to intervene in land supply. When the government strengthens the intervention in the land market and increases the proportion of allocated land, the land area available for transfer, degree of marketization, and scale of the residential land are reduced. Therefore, land market is subject to government intervention influence, and the lower the allocated proportion to the total area, the greater the residential land.

\subsubsection{Regional differences in government land behavior}

Geography matters in Chinese housing markets where land is discretely allocated by the government. Existing research found that urban land expansion in China is highly uneven across regions, and the degree of land expansion in the western region is lower than that in the eastern region (Liu et al., 2018c). Significant regional differences affect China's land market development on illegal land use. Moreover, the impact of land market development in the eastern region on illegal land use is more pronounced than that in the central and western regions.

Based on the results estimated by sub-regional GMM, the correlation coefficient between the residential land vacancy scale and the residential land price in the eastern region is positive under the $10 \%$ significance level. Therefore, the coefficient is significant. A one unit increase in residential land price in the eastern region can also increase the residential land hoarding scale by 0.26 hectares, indicating that the residential land price in the eastern region significantly affects the residential land hoarding scale in the same region. Model 9-16 in Table 5 provides the estimation results, which confirm that the land prices and the local governments' land hoarding in central and western regions have a positive correlation. However, the resulting coefficient is insignificant and cannot explain the existence of speculative land hoarding between land and local governments in the mid-west region.

The GMM results in different regions indicate the difference between land price and local governments' land. In recent years, national urbanization has undergone rapid development in the eastern region. High levels of economic development can make use of small land areas, resulting in high local governments' financial dependence on land compared with the mid-west region. The descriptive analysis of data has also confirmed this point. By contrast, the relationship between residential land price in the central and western regions and the size of residential land hoarding by local governments is insignificant. However, the basis for economic development, public facilities, and provided support are not enough. This area is mainly supported through government supply of pure public goods to meet infrastructure requirement. Therefore, a large gap exists between land value and the eastern region. A significant positive correlation also exists between fixed asset investment and per capita GDP with local governments' residential land hoarding area. This relationship indicates that regional economic development level and investment activity affect local governments' land behavior and urban expansion. 


\begin{tabular}{|c|c|c|c|c|c|c|c|c|c|c|c|c|c|}
\hline \multirow{3}{*}{$\begin{array}{l}\frac{+}{v} \\
\frac{\vec{v}}{0} \\
\frac{0}{\Sigma}\end{array}$} & $\sum_{0}$ & 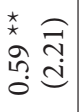 & 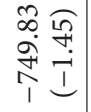 & 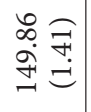 & 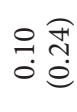 & 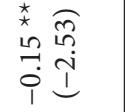 & 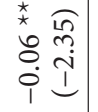 & 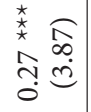 & 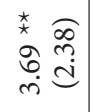 & 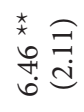 & $\begin{array}{l}8 \\
: \\
\circ\end{array}$ & $\stackrel{\llcorner}{\Omega}$ & $\widetilde{\sigma}$ \\
\hline & 壵 & 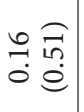 & 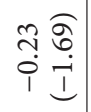 & 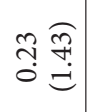 & 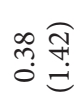 & 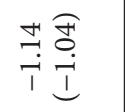 & 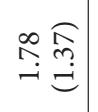 & 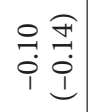 & 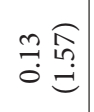 & $\begin{array}{l}\infty \\
\stackrel{\infty}{0} \\
i \stackrel{0}{i} \\
i\end{array}$ & ָे & $\begin{array}{l}0 \\
\infty \\
\infty \\
\infty\end{array}$ & $\stackrel{\circ}{\vec{\sim}}$ \\
\hline & ח) & 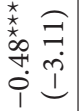 & \begin{tabular}{ll}
1 & \multicolumn{2}{c}{} \\
\hdashline & 0 \\
0 & 1 \\
1 & 1
\end{tabular} & 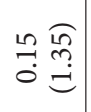 & 忨 & $\stackrel{\substack{\hat{m} \\
0}}{\stackrel{m}{e}}$ & 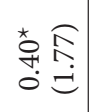 & 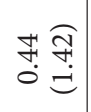 & 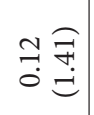 & $\begin{array}{l}\hat{\widehat{N}} \\
0 \\
0 \\
0\end{array}$ & $\begin{array}{l}\stackrel{0}{0} \\
\vdots\end{array}$ & 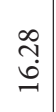 & $\stackrel{\circ}{\sim}$ \\
\hline \multirow{3}{*}{$\begin{array}{l}m \\
\frac{\tilde{v}}{0} \\
\frac{0}{\Sigma}\end{array}$} & $\sum_{j}$ & $\begin{array}{ll}0 & \widehat{\Omega} \\
m & 0 \\
0 & \stackrel{0}{=}\end{array}$ & & & 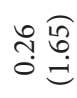 & 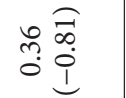 & 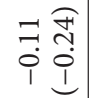 & 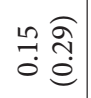 & \begin{tabular}{cc}
$m$ & $\stackrel{0}{0}$ \\
\hdashline & $\stackrel{\Xi}{=}$
\end{tabular} & 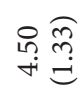 & $\begin{array}{l}0 \\
0 \\
0\end{array}$ & $\begin{array}{l}0 \\
\stackrel{1}{i} \\
m\end{array}$ & $\widetilde{\Omega}$ \\
\hline & 牙 & 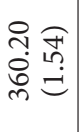 & & & 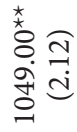 & 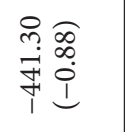 & 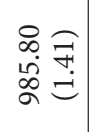 & 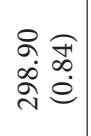 & 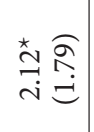 & 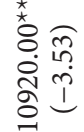 & $\stackrel{m}{0}$ & $\begin{array}{c}\vec{N} \\
\infty\end{array}$ & $\stackrel{\circ}{\vec{\sim}}$ \\
\hline & $\tilde{0}$ & 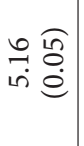 & & & 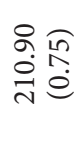 & 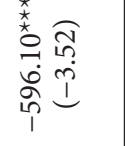 & 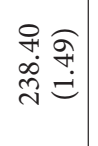 & 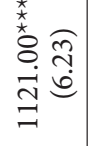 & 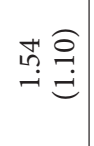 & 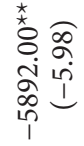 & ָे & $\stackrel{n}{\stackrel{0}{\sim}}$ & $\stackrel{\circ}{\sim}$ \\
\hline \multirow{3}{*}{ 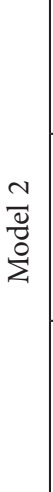 } & $\sum_{0}$ & 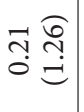 & & 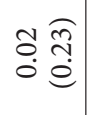 & & 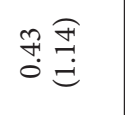 & $\begin{array}{ll}m & \widehat{\sigma} \\
3 & \Omega \\
1 & 0 \\
1\end{array}$ & 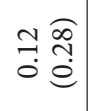 & 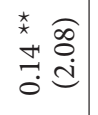 & 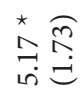 & $\overrightarrow{0}$ & $\begin{array}{l}\stackrel{\infty}{1} \\
\text { ஸn } \\
n\end{array}$ & 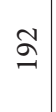 \\
\hline & 至 & 号 & & 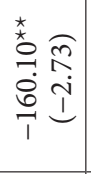 & & 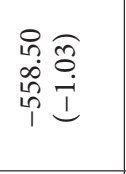 & $\begin{array}{l}\stackrel{8}{\circ} \\
\dot{0} \\
\stackrel{0}{=} \\
=\end{array}$ & 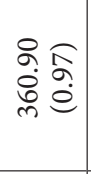 & 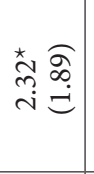 & 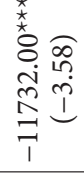 & $\stackrel{m}{0}$ & $\underset{\infty}{\infty}$ & $\stackrel{\circ}{\sim}$ \\
\hline & $\stackrel{3}{0}$ & 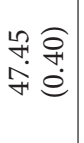 & & 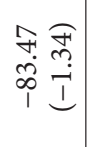 & & 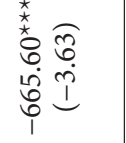 & 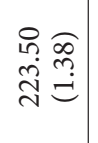 & 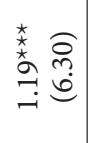 & 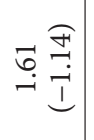 & 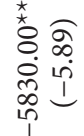 & ָิ & $\underset{\sim}{\vec{\sim}}$ & $\stackrel{\circ}{\sim}$ \\
\hline \multirow{3}{*}{$\begin{array}{l}\overrightarrow{\bar{v}} \\
\overline{0} \\
\bar{\Sigma}^{2}\end{array}$} & $\sum_{0}$ & 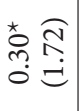 & 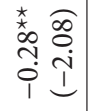 & & & 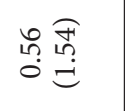 & 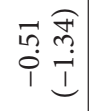 & 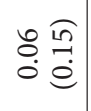 & $\begin{array}{l}\hat{\sigma} \\
\stackrel{\partial}{\hat{\sigma}} \\
\dot{e}\end{array}$ & 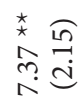 & $\begin{array}{l}0 \\
0 \\
0\end{array}$ & హे & $\widetilde{\Omega}$ \\
\hline & 牙 & 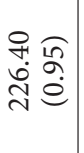 & 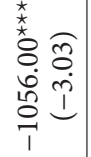 & & & 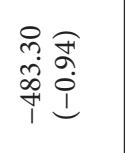 & 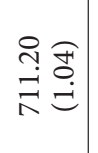 & $\begin{array}{l}\text { iñ } \\
\text { 令 } \\
\text { hn }\end{array}$ & 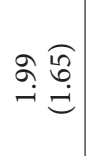 & 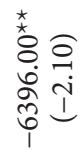 & $\stackrel{m}{\tilde{O}}$ & ڤై & $\stackrel{\circ}{\sim}$ \\
\hline & $\stackrel{n}{0}$ & 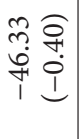 & 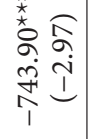 & & & 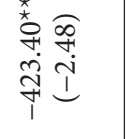 & 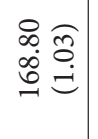 & 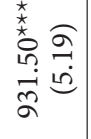 & 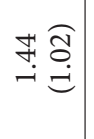 & 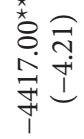 & ô. & 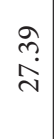 & $\stackrel{\circ}{\sim}$ \\
\hline 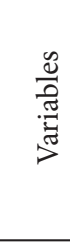 & & 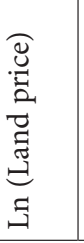 & 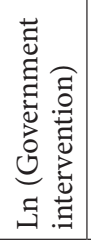 & 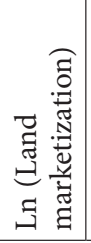 & 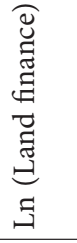 & 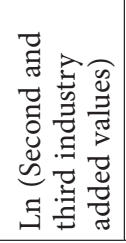 & 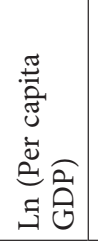 & 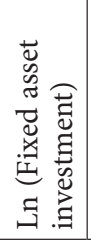 & 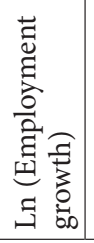 & 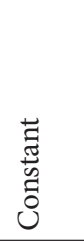 & 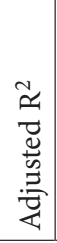 & 山 & 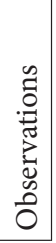 \\
\hline
\end{tabular}




\begin{tabular}{|c|c|c|c|c|c|c|c|c|c|c|c|c|}
\hline \multirow{4}{*}{ 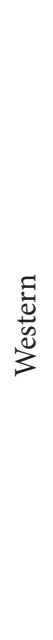 } & 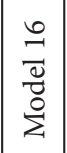 & 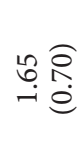 & 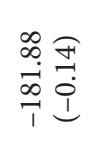 & 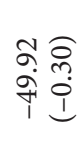 & ণิ ণิ & : & 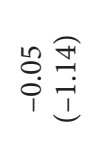 & 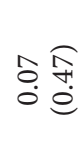 & 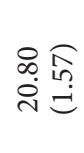 & ల్ర & 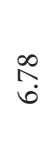 & $\hat{\sigma}$ \\
\hline & $\begin{array}{l}\stackrel{n}{a} \\
\vec{\nabla} \\
\bar{\Delta} \\
\Sigma\end{array}$ & 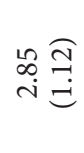 & & & $\begin{array}{ll} & 0 \\
0 & 0 \\
0 & 0 \\
i & 9 \\
1 & 1\end{array}$ & 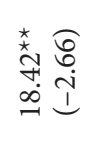 & 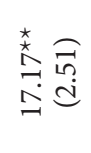 & 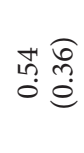 & 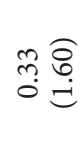 & $\begin{array}{l}0 \\
0 \\
0\end{array}$ & $\begin{array}{l}\stackrel{0}{\pi} \\
\vec{i}\end{array}$ & $\hat{\sigma}$ \\
\hline & 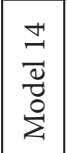 & 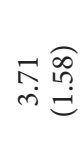 & & 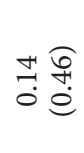 & & 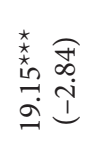 & 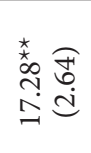 & ஸे & 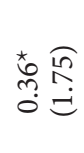 & m. & $\underset{\infty}{\vec{\infty}}$ & $\hat{\sigma}$ \\
\hline & $\begin{array}{l}\stackrel{m}{\vec{v}} \\
\stackrel{\vec{v}}{0} \\
\stackrel{\Delta}{\Sigma}\end{array}$ & 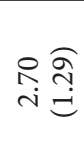 & 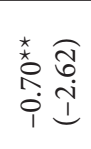 & & & 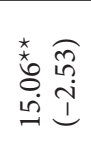 & 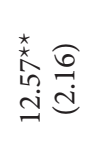 & 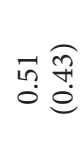 & 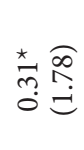 & ते & 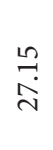 & $\hat{\sigma}$ \\
\hline \multirow{4}{*}{ 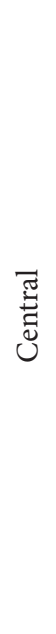 } & 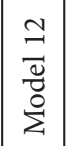 & 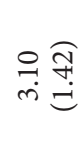 & 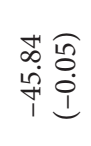 & 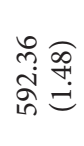 & 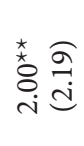 & సָे & 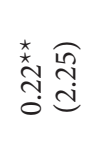 & 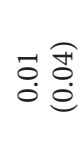 & 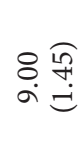 & $\exists$ & $\tilde{\text { n̆ }}$ & in \\
\hline & 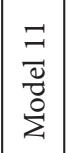 & 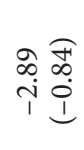 & & & 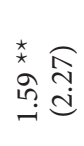 & 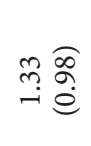 & 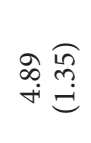 & 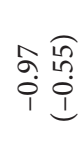 & 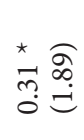 & $\stackrel{m}{0}$ & fึ? & in \\
\hline & $\begin{array}{l}\stackrel{0}{2} \\
\stackrel{\vec{v}}{\tilde{0}} \\
\stackrel{0}{\Sigma}\end{array}$ & 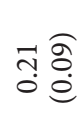 & & 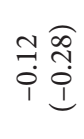 & & 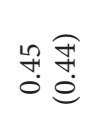 & 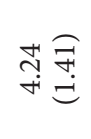 & 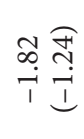 & 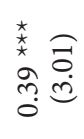 & $\stackrel{?}{\stackrel{?}{0}}$ & $\begin{array}{l}0 \\
\infty \\
\infty\end{array}$ & in \\
\hline & $\begin{array}{l}\frac{a}{\vec{v}} \\
\frac{\overrightarrow{0}}{\Sigma}\end{array}$ & $\begin{array}{l}0 \\
\text { 옹 } \\
0\end{array}$ & 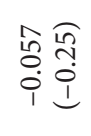 & & & 药 & 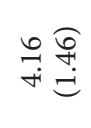 & 资各 & 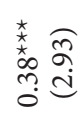 & ?̊? & 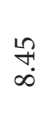 & in \\
\hline \multirow{4}{*}{ 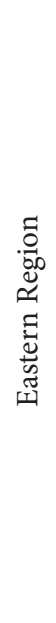 } & $\begin{array}{l}\infty \\
\vec{\nabla} \\
\bar{z} \\
\Sigma\end{array}$ & 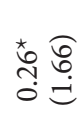 & 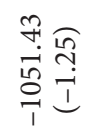 & 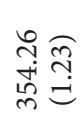 & 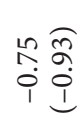 & 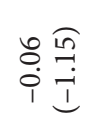 & 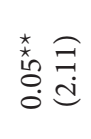 & 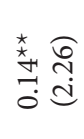 & 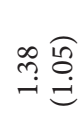 & $\stackrel{\infty}{\stackrel{\infty}{0}}$ & $\stackrel{\text { o }}{-}$ & $\stackrel{2}{\imath}$ \\
\hline & $\mid \begin{array}{l}n \\
\bar{\nabla} \\
\tilde{\Delta} \\
\Sigma\end{array}$ & 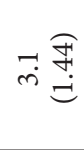 & & & 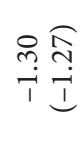 & 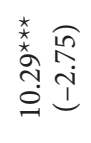 & 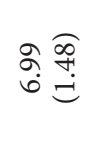 & 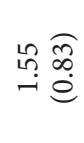 & 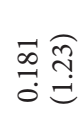 & ڤ̊ & $\stackrel{N}{\stackrel{N}{-}}$ & $\stackrel{ }{\gtrless}$ \\
\hline & $\begin{array}{l}0 \\
\vec{\nabla} \\
\tilde{z} \\
\Sigma\end{array}$ & 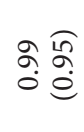 & & సે $\stackrel{\widehat{\partial}}{\stackrel{\Xi}{\Xi}}$ & & 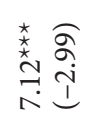 & 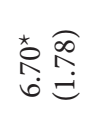 & 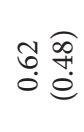 & 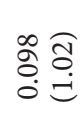 & $\ddot{\circ}$ & $\begin{array}{l}\stackrel{\alpha}{\text { i }} \\
\text { in }\end{array}$ & $\stackrel{2}{\gtrless}$ \\
\hline & 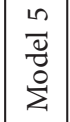 & 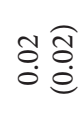 & 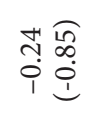 & & & 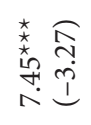 & 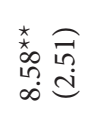 & 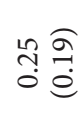 & 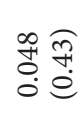 & $\stackrel{\delta}{0}$ & $\underset{\dot{r}}{\tilde{r}}$ & $\stackrel{\mathfrak{N}}{\wedge}$ \\
\hline \multicolumn{2}{|c|}{ 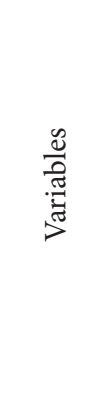 } & 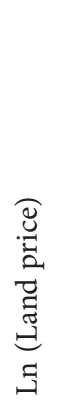 & 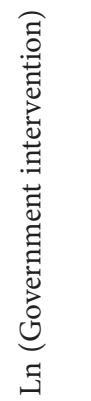 & 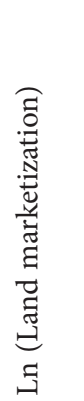 & 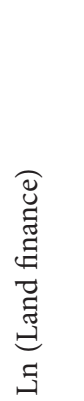 & 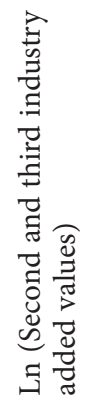 & 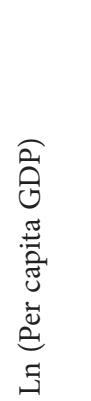 & 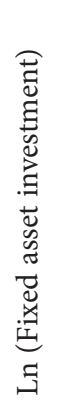 & 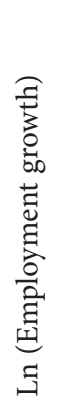 & 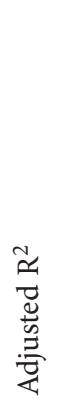 & 山 & 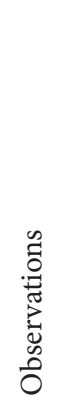 \\
\hline
\end{tabular}




\section{Conclusions}

This study uses 31 provincial-level panel data from 2004 to 2015 to establish a systematic GMM estimation model, which analyzes the impact of government intervention, land marketization level, and land price level on local governments' land hoarding scale and speculation behavior. The following results are obtained.

Hypothesis 1 is confirmed. Land price has a significant positive impact on local governments' land hoarding scale. When the local price of residential land is higher, local governments will accumulate more land. Specifically, the land price in the whole country has increased by one unit, and the land hoarding area of local governments has increased by 0.585 hectares. The results also indicate that local governments speculate on land. GMM estimates of data across the country have revealed regional differences in land speculation. If the residential land price in the eastern region increases by one unit, then local governments' residential land hoarding scale increases by 0.26 hectares, which is more evident than the land speculation in central and western regions. The policy system transfers land appreciation to governments. However, the actual situation is more complicated than expected. Local governments' land hoarding scale is staggering, indicating that local governments have become speculators in the land market.

Hypothesis 2 is also supported. Government intervention can negatively affect the land hoarding scale. This research measures the extent to which governments intervene in the land market using the land transfer other than administrative allocation. The more the administrative allocations, the greater the degree of government intervention and the smaller the land scale available for land market transfer. Therefore, land hoarding decreases. The empirical results show that the smaller the degree of government intervention, the smaller the scale of market transactions and the lesser the speculative behavior of the government. Moreover, sub-regional empirical results are confirmed.

Hypothesis 3 has not been confirmed. A certain relationship is found among variables that can be generated on the basis of descriptive statistics. In keeping with the policy background factors, the data used in this study are the comprehensive panel data acquired after fully implementing the bidding and auction system. Given the limited data sample size, the degree of land marketization and governments' land financial dependence have not produced significant results in the model. Therefore, future studies must interpret this hypothesis through data updates and model corrections.

A strong endogeneity exists between local governments' land hoarding area and land price. The traditional simple linear regression model cannot solve the endogenous problem and affect the model estimation results. GMM estimation method can effectively eliminate the endogenous problem between land area and land price by using instrumental variables, making the results stable and in line with expectations.

\section{Acknowledgements}

This work was supported by National Social Science Fund of China (No. 16BJL053), Zhejiang Provincial Natural Science Foundation (No. LY18G030039, LQ19E080016), National Natural Science Foundation of China (71974169).

\section{Conflict of interests}

The authors declare no conflict of interests.

\section{References}

Bentick, B. L. (2010a). Improving the allocation of land between speculators and users: taxation and paper land. Economic Record, 48, 18-41.

https://doi.org/10.1111/j.1475-4932.1972.tb01534.x

Bentick, B. L. (2010b). The allocation of land between speculators and users under a land ownership tax: a reply. Economic Record, 50, 449-450.

https://doi.org/10.1111/j.1475-4932.1974.tb00804.x

Bourassa, S. C., Hoesli, M., Scognamiglio, D., \& Zhang, S. (2010). Land leverage and house prices. Regional Science and Urban Economics, 41, 134-144. https://doi.org/10.2139/ssrn.1715532

Davis, M. A. (2009). The price and quantity of land by legal form of organization in the United States. Regional Science and Urban Economics, 39, 350-359.

https://doi.org/10.1016/j.regsciurbeco.2009.01.002

Deng, X. Z., Huang, J. K., Rozelle, S., \& Uchida, E. (2006). Growth, population and industrialization, and urban land expansion of China. Journal of Urban Economics, 63, 96-115. https://doi.org/10.1016/j.jue.2006.12.006

Dong, Y. L. (2016). A note on geographical constraints and housing markets in China. Journal of Housing Economics, 33, 15-21. https://doi.org/10.1016/j.jhe.2016.06.003

Du, H. Y., Ma, Y. K., \& An, Y. B. (2010). The impact of land policy and the relation between housing land prices: evidence from China. Quarterly Review of Finance and Economics, 51, 19-27. https://doi.org/10.1016/j.qref.2010.09.004

Du, J. F., \& Peiser, R. B. (2014). Land supply, pricing and local governments' land hoarding in China. Regional Science and Urban Economics, 48, 180-189.

https://doi.org/10.1016/j.regsciurbeco.2014.07.002

Golland, A., \& Boelhouwer, P. (2002). Speculative housing supply land and housing, markets: a comparison. Journal of Property Research, 19, 231-251.

https://doi.org/10.1080/09599910210151332

Goodman, A. C., \& Thibodeau, T. G. (2008). Where are the speculative bubbles in US housing markets? Journal of Housing Economics, 17, 117-137. https://doi.org/10.1016/j.jhe.2007.12.001

Grout, C. A., Jaeger, W. K., \& Plantinga, A. J. (2011). Land-use regulations and property values in Portland, Oregon: a regression discontinuity design approach. Regional Science \& Urban Economics, 41, 98-107. https://doi.org/10.1016/j.regsciurbeco.2010.09.002

Ho, S., \& Lin, G. (2003). Emerging land markets in rural and urban China: policies and practices. China Quarterly, 175, 681-707. https://doi.org/10.1017/S0305741003000407

Huang, D., \& Chan, R. C. K. (2018). On 'Land Finance' in urban China: theory and practice. Habitat International, 75, 96-104. https://doi.org/10.1016/j.habitatint.2018.03.002 
Hui, C. M. (2004). An empirical study of the effects of land supply and lease conditions on the housing market: a case of Hong Kong. Property Management, 22, 127-154. https://doi.org/10.1108/02637470410532402

Hui, E. C. M., Zhong, J., \& Yu, K. (2017). Property prices, housing policies for collateral and resale constraints. International Journal of Strategic Property Management, 21(2), 115-128. https://doi.org/10.3846/1648715X.2016.1249984

Ihlanfeldt, K. R. (2006). The effect of land use regulation on housing and land prices. Journal of Urban Economics, 61, 420-435. https://doi.org/10.1016/j.jue.2006.09.003

Jiang, M., Xin, L. J., Li, X. B., \& Tan, M. H. (2016). Spatiotemporal variation of China's state-owned construction land supply from 2003 to 2014. Sustainability, 8, 1-16. https://doi.org/10.3390/su8111137

Koster, H. R. A., Ommeren, J. V., \& Rietveld, P. (2012). Bombs, boundaries and buildings: a regression-discontinuity approach to measure costs of housing supply restrictions. Regional Science \& Urban Economics, 42, 631-641. https://doi.org/10.1016/j.regsciurbeco.2012.02.007

Lavin, A. M., \& Zorn, T. S. (2001). Empirical tests of the fundamental-value hypothesis in land markets. The Journal of Real Estate Finance and Economics, 22, 99-116. https://doi.org/10.1023/A:1007883427681

Lichtenberg, E., \& Ding, C. R. (2008). Assessing farmland protection policy in China. Land Use Policy, 25, 59-68. https://doi.org/10.1016/j.landusepol.2006.01.005

Lin, G., \& Ho, S. (2005). The state, land system, and land development processes in contemporary China. Annals of the Association of American Geographers, 95, 411-436. https://doi.org/10.1111/j.1467-8306.2005.00467.x

Liu, G. W., Li, K. J., Shrestha, A., Martek, I., \& Zhou, Y. (2018a). Strategic business model typologies evident in the Chinese real-estate industry. International Journal of Strategic Property Management, 22(6), 501-515. https://doi.org/10.3846/ijspm.2018.6275

Liu, Y. S., Li, J. T., \& Yang, Y. Y. (2018b). Strategic adjustment of land use policy under the economic transformation. Land Use Policy, 74, 5-14.

https://doi.org/10.1016/j.landusepol.2017.07.005

Liu, Z., Liu, S. H., Qi, W., \& Jin, H. R. (2018c). Urban sprawl among Chinese cities of different population sizes. Habitat International, 79, 89-98.

https://doi.org/10.1016/j.habitatint.2018.08.001

Mercy, B. L. (2011). Capturing land value increment to finance infrastructure investment-Possibilities for South Africa. Urban Forum, 22, 37-52.

https://doi.org/10.1007/s12132-010-9108-3

Murray, M. P. (2006). Avoiding invalid instruments and coping with weak instruments. Journal of Economic Perspectives, 20, 111-132. https://doi.org/10.1257/jep.20.4.111

Nichols, J. B., Oliner, S. D., \& Mulhall, M. R. (2013). Swings in commercial and residential land prices in the United State. Journal of Urban Economics, 73, 57-76. https://doi.org/10.1016/j.jue.2012.06.004

Okumura, T. (1997). Housing investment and residential land supply in Japan: an asset market approach. Journal of the Japanese and International Economies, 11, 27-54. https://doi.org/10.1006/jjie.1996.0361

Ooi, J., Sirmans, C. F., \& Turnbull, G. (2011). Government supply of land in a dual market. Real Estate Economics, 39, 167-184. https://doi.org/10.1111/j.1540-6229.2010.00290.x

Quaife, M. M., \& Hoyt, H. (1934). One hundred years of land values in Chicago: the relationship of the growth of Chicago to the rise in its land values, 1830-1933. The Mississippi Valley Historical Review, 21(1), 108. https://doi.org/10.2307/1896433

Rancich, M. T. (1970). Land value changes in an area undergoing urbanization. Land Economics, 46, 32-40.

https://doi.org/10.2307/3145421

Remeikienè, R., Gasparènienè, L., \& Ginevičius, R. (2019). The specificity of the investment in land as in real estate. International Journal of Strategic Property Management, 23(4), 244-255. https://doi.org/10.3846/ijspm.2019.8092

Schmid, A. A. (1968). Converting land from rural to urban uses. American Journal of Agricultural Economics, 50(4), 1077-1078. https://doi.org/10.2307/1237657

Shen, X., Huang, X., Li, H., \& Li, Y. (2018). Exploring the relationship between urban land supply and housing stock: evidence from 35 cities in China. Habitat International, 77, 80-89. https://doi.org/10.1016/j.habitatint.2018.01.005

Su, F. B., Tao, R., Xi, L., \& Li, M. (2012). Local officials' incentives and China's economic growth: tournament thesis reexamined and alternative explanatory framework. China \& World Economy, 20, 1-18. https://doi.org/10.1111/j.1749-124X.2012.01292.x

Tewfik, M. (1989). Urban land in Jordan: issues and policies. Cities, 6, 119-135. https://doi.org/10.1016/0264-2751(89)90065-6

Tian, L., \& Ma, W. J. (2008). Government intervention in city development of China: a tool of land supply. Land Use Policy, 26, 599-609. https://doi.org/10.1016/j.landusepol.2008.08.012

Wang, Q., Xu, J. X., \& Zhang, Y. (2012). An empirical study of the impact of land finance on housing prices. Advances in Applied Economics \& Finance, 2, 153-170.

Wen, H. Z., Chu, L. J., Zhang, J. F., \& Xiao, Y. (2018). Competitive intensity, developer expectation, and land price: evidence from Hangzhou, China. Journal of Urban Planning and Development, 144, 1-11.

https://doi.org/10.1061/(ASCE)UP.1943-5444.0000490

Wu, G. L., Feng, Q., \& Li, P. (2015b). Does local governments' budget deficit push up housing prices in China? China Economic Review, 35, 183-196.

https://doi.org/10.1016/j.chieco.2014.08.007

Wu, Q., Li, Y. L., \& Yan, S. Q. (2015a). The incentives of China's urban land finance. Land Use Policy, 42, 432-442. https://doi.org/10.1016/j.landusepol.2014.08.015

Ye, L. F., Huang, X. J., Yang, H., Chen, Z. G., Zhong, T. Y., \& Xie, Z. L. (2018). Effects of dual land ownerships and different land lease terms on industrial land use efficiency in Wuxi City, East China. Habitat International, 78, 21-28. https://doi.org/10.1016/j.habitatint.2018.04.011

Zhang, H., Zhang, Y., \& Chen, T. T. (2016). Land remise income and remise price during China's transitional period from the perspective of fiscal decentralization and economic assessment. Land Use Policy, 50, 293-300. https://doi.org/10.1016/j.landusepol.2015.10.008

Zhang, J. P., Fan, J. Y., \& Mo, J. W. (2017). Government the intervention, land market, and the urban development: evidence from Chinese cities. Economic Inquiry, 55, 115-136. https://doi.org/10.1111/ecin.12353

Zhong, T., Qian, Z., Huang, X. J., Zhao, Y. T., Zhou, Y., \& Zhao, Z. H. (2018). Impact of the top-down quota-oriented farmland preservation planning on the change of urban land-use intensity in China. Habitat International, 77, 71-79. https://doi.org/10.1016/j.habitatint.2017.12.013 